KHAZANAH MULTIDISIPLIN

VOL 2 NO 12021

https://journal.uinsgd.ac.id/index.php/kl

\title{
POLITIK HUKUM PIDANA KEKERASAN SEKSUAL DALAM RKUHP
}

\author{
Nurul Isnina Syawalia Arifah Nasution \\ Program Studi Magister Ilmu Hukum, Pascasarjana, UIN Sunan Gunung \\ Djati Bandung, Indonesia \\ E-mail: nurulisnina97@gmail.com
}

\begin{abstract}
Sexual violence is an act that indeed has not been prevented by the government, especially in terms of protection of victims of sexual violence in the present needs to be updated about the Criminal Code that regulates specific acts of sexual violence so that there is protection for these victims. With the draft law on the Elimination of Sexual Violence or what we commonly call the PKS Act, the existence of the law is a refinement of the Criminal Code book as the Criminal Code has the characteristic of the Lex Generalis whereas the Sexual Violence abolition bill become the Lex Specialist. To achieve a particular goal of a country, the authorities are authorized to form legal products which contain legal political policies both national and international scale objectives. In Indonesia, the rues regarding criminal law politics are regulated in a policy called criminal policy which is implemented through the preparation of laws which are arranged in the criminal law books, criminal procedure codes, and other laws in which there are rules regarding criminal provisions.
\end{abstract}

Keyword : Political law, political criminal law, violence sexsual

\begin{abstract}
ABSTRAK
Kekerasan seksual merupakan suatu tindakan yang memang sampai saat ini belum bisa dicegah oleh pemerintah, terutama dalam hal perlindungan terhadap korban kekerasan seksual pada dewasa ini perlu adanya pembaharuan terhadap KUHP yang mengatur mengenai tindak pidana kekerasan seksual secara spesifik sehingga ada perlindungan terhadap korban tersebut. Dengan adanya Rancangan Undang-undang Penghapusan Kekerasan Seksual atau biasa kita sebut undang- undang PKS maka dengan adanya undang-undang tersebut menjadi penyempurna dari Kitab Undang-undang Hukum Pidana sebagaimana KUHP ini memiliki khas na Lex Generalis sedangkan RUU Penghapusan Kekerasan Seksual ini menjadi Lex Spesialis. Untuk mencapai tujuan tertentu suatu Negara, para penguasa yang berwenang membentuk produk hukum yang didalamnya mengandung kebijakan politik hukum baik itu tujuan skala nasional ataupun internasional. Di Indonesia aturan mengenai politik hukum pidana diatur dalam suatu kebijakan yang disebut kebijakan kriminal yang diterapkan melalui penyusunan undangundang yang disusun dalam kitab undang-undang hukum pidana, kitab undang-undang hukum acara pidana, dan undang-undang lainnya yang didalamnya terdapat aturan mengenai ketentuan pidana.
\end{abstract}

Kata Kunci : Kekerasan Seksual,Politik Hukum, Politik Hukum Pidana

\section{PENDAHULUAN}

Dalam UU NRI 1945 Pasal 1 Ayat 3 disebutkan bahwa Indonesia merupakan Negara berlandaskan hukum. Oleh karenanya pelaksanaan tugas dan wewenang pemerintah didasarkan pada pedoman hukum dan 
bukan atas kesewenang-wenangan semata. Hukum dan keadilan bagi semua warga negara merupakan asas dasar dari negara hukum. Yang berarti bahwa segala kewenangan dan tindakan alat alat perlengkapan negara atau penguasa, semata-mata berdasarkan hukum atau dengan kata lain diatur oleh hukum. Hal yang demikian akan mencerminkan keadilan bagi interaksi sosial masyarakat .( Didi Nazmi, 1992)

Kesejahteraan umum merupakan tujuan utama dari negara hukum yang tertuang dalam pembukaan undang-undang dasar negara republik Indonesia tahun 1945. konsepsi yang digunakannya pun adalah konsep hukum kesejahteraan negara. Timbulnya Konsep ini merupakan timbal balik dari gagalnya konsep yang sudah berlaku sebelumnya yaitu konsep legal state. Konsep hokum kesejahteraan Negara yaitu pemerintah sebagai penanggungjawab utama bagi tolak ukur masyarakat yang sejahtera. Ciri utamanya adalah pemerintah memiliki kewajiban dalam mewujudkan kesejahteraan masyarakat banyak. Dengan kata lain, ajaran welfare state merupakan perwujudan nyata dari prinsip staatsonthouding, yang mana prinsip ini memiliki batasan terhadap peran negara dalam campur tangan perkembangan ekonomi dan perkembangan sosial di masyarakat. Prinsip staatsonthouding beralih menjadi prinsip staatsbemoeienis yang menuntut Negara agar terlibat secara aktif dalam perkembangan ekonomi dan sosial di masyarakat banyak dengan tujuan untuk mewujudkan kesejahteraan masyarakat banyak, selain memberikan rasa tertib dan aman terhadap masyarakat.(Ridwan HR, 2006)

Politik hukum nasional adalah merupakan bagian dari kebjakan Negara lainnya terutama dibidang kebijakan sosial, kesejahteraan sosial dan pertahanan sosial termasuk keamanan nasional. Bidang -bidang politik hukum nasional itu meliputi bagian-bagian hukum yang menjadi kebutuhan bagian-bagian yang perlu diatur oleh hukum termasuk di dalamnya politik hukum pidana. Akan tetapi dalam pelaksanaan nya bisa terintegrasi secara bersama dari semua bagian, sepertikebijakan kriminalisasi, kebijakan peradilan pidana, kebijakan penegakan hukum, 
kebijakan administrasi, kebijakan hukum dan kebijakan hukum pidana termasuk di dalamnya politik hukum kekerasan seksual.

Perlakuan tidak baik terhadap perempuan yang bersifat seksual terlepas dari terjadinya hubungan intim atau tidak dengan mengesampingkan status pelaku dan korban termasuk dalam kategori kekerasan seksual. Kekerasan seksual tidak hanya mengacu kepada perkosaan atau persetubuhan saja akan tetapi lebih konprehensif mencakup segala jenis tindakan yang tidak dilandasi atas dasar suka sama suka dan juga tidak hanya sebatas penetrasi laki-laki ke perempuan, tetapi juga melingkupi alat atau benda yang digunakan dengan tujuan memberikan efek penderitaan kepada korban.( Ende Hasbi, 2016)

Agar suatu Negara bisa mencapai tujuan untuk mengatasi problema kekerasan seksual maka Negara melakukan terobosan politik hokum dengan cara merumuskan Rancangan Undang-undang yaitu undangundang mengenai penghapusan kekerasan seksual, juga sebagai penyempurna dari aturan yang terdapat dalam kitab undang-undang hukum pidana. Dengan begitu kitab undang-undang hukum pidana ini menjadi lex generalis sedangkan RUU kekerasan sexsual itu menjadi lex spesialis terhadap adanya kekerasan sexsual.

\section{METODE PENELITIAN}

Penelitian ini merupakan suatu cara pengembangan ilmu pengetahuan yang ditujukan untuk memngungkapkan fenomena empiris, fakta secara kronologis dan konsisten dengan mengadakan analisis konstruksi, spesifikasi penelitian menggunakan penelitian dengan menggambarkan dan menganalisa secara akurat sesuai dengan keadaan yang sebenarnya terhadap suatu fenomena yang terjadi. (Soejono, 2015) pendekatan yang digunakan yaitu berdasarkan undang-undang yang berlaku dengan cara meneliti hukum, bahan pustaka atau data sekunder sebagai bahan dasar untuk diteliti dengan cara mengadakan penelurusan terhadap peraturan-peraturan dan literature- literatur yang berkaotan 
KHAZANAH MULTIDISIPLIN

VOL 2 NO 12021

https://journal.uinsgd.ac.id/index.php/kl

dengan masalah pidana dalam kekerasan seksual.

\section{HASIL DAN PEMBAHASAN}

Politik hukum pidana merupakan salah satu cabang bagian terpenting dari kajian ilmu hukum di Indonesia selain itu juga dapat menjadi alat pembantu dalam memahami konsep teorinya sebagai bahan untuk kajian selanjutnya, dan kajian secara sektoral masih sangan dibutuhkan untuk pengembangan kajian hukum dimasa yang akan datang, misalnya dalam mengkaji politik hukum perdata, politik hukum pidana, dan sebagainya. Hal ini jga menunjukan bahwa pendekatan dalam kajian hukum semakin meluas yakni selain pendekatan normatif yuridis juga bisa melalui pendekatan sosio legal.

Menurut Sunaryati Hartono dan Mahfud MD menyatakan dalam politik hukum harus ditempatkan sebagai suatu alat yang berfungsi dalam tatanan social dan tatanan hukum tertentu demi menggapai visi misi tujuan masyarakat atau Negara. Dalam pendapatnya Ruslan Shaleh menyatakan, bahwa undang- undang adalah satu dari sekian banyak alat yang digunakan untuk menjalankan kebijakan pemerintah. Dari berbagai pemahaman tentang politik hukum tersebut dan mengacu terhadap pendapat Mahfud MD yang mengatakan political law atau politik hukum diibaratkan dua sisi mata uang yang tidak dapat dipisahkan yakni :

1. Politik hukum merupakan pedoman atau "legal policy" dari lembaga Negara dalam perancangan suatu hukum

2. Politik hukum merupakan suatu sistem yang digunakan untuk menentukan dan menganalisis hukum yang dibuat sudah sesuai atau tidak dengan kerangka pikir legal policy agar tercapainya suatutujuan Negara.

3. Politik hukum jika dihubungkan pada pencapaian tujuan Negara, maka politik hukum itu sekurangnya merangkumi hal-hal sebagai berikut:

4. Tujuan Negara yang diidamkan masyarakat Indonesia sebagai 
KHAZANAH MULTIDISIPLIN

VOL 2 NO 12021

https://journal.uinsgd.ac.id/index.php/kl

orientasi dan pemandu politik hukum, termsuk penggalian nilai- nilai dasar tujuan Negara dalam pembangunan hukum nasional.

5. Perumusan sistem hukum nasional sebagai jalan mewujudkan tujuan nasional dengan berbagai faktor yang memengaruhinya.

6. Melakukan penyusunan dan menuangkan kerangka pikir dalam merumuskan kebijakan hukum

7. Substansi dari hukum nasional dengan berbagai faktor yang memengaruhinya.

Proses pengawalan terhadap hukum dengan prolegnas dan melakukan pengujian terhadap produk hukum oleh lembaga peradilan, melakukan upaya terhadap lembaga legislative untuk mengubah peraturan perundang-undangan, dan sebagainya(Mahfud, 2009)

Menurut marc ancel konsep dalam politik hokum khususnya hokum pidana di era modern criminal science memiliki 3 (tiga) pokok pembahasan yaitu pembahasan mengenai kriminologi, criminal law, dan penal policy.(Barda, 2005) Maksud dari penal policy yaitu disiplin ilmu dan seni yang memiliki tujuan untuk mengatur hukum positif secara lebih efisien dan sebagai pedoman untuk pembuat undang-undang, untuk pengadilan dan untuk para penyelenggara putusan pengadilan.

Pembahasan mengenai sistem politik hukum pidana, dalam beberapa literature banyak menggunakan istilah kebijakan hukum pidana, kebijakan kriminal, serta kebijakan legislative. Kemudian pengertian ini perlu dikaji lebih dalam berkenaan dengan ketetapan, serta maknanya. Sebab kebijakan mempunyai persamaan kata dari "policy" yang penggunaannya lebih memiliki khas dalam teknis eksekutif atau administratif. Oleh karenanya jika merujuk asal kata politik hukum, maka menjadi "rechtpolitiek", hingga sepatutnya kata politik hukum pidana lebih sepadan dengan alam pikir dengan berbagai disiplin ilmu pengetahuan dan rancangan yang akan dibincangkan. Pengertian kebijakan atau politik 
hukum pidana dapat dilihat dari politik hukum maupun dari politik kriminal. Adapun Prof Sudarto berpendapat bahwa politik hukum pidana berarti melakukan pilihan untuk merumuskan dan menciptakan sistem UU pidana yang relevan berarti harus terpenuhii syarat keadilan serta kegunaan untuk masyarakat. Adapun pada waktu lain Dia menyampaikan, pelaksanaan politik hukum pidana mengandung arti upaya untuk mewujudkan aturan UU pidana yang relevan dengan situasi dan kondisi yang temporal dan kondisi dimasa mendatang. Dengan demikian jika ditinjau dari sisi ilmu politik hukum, maka bermakna tata cara mengupayakan, menciptakan dan merumuskan sistem UU pidana yang relevan. ‘

Adapun berbagai macam tindakan pelecehan kepada perempuan yang sudah tercantum pada Pasal 2 Universal Declaration of Human Right, mencakup: kekerasan terhadap fisik, seksual, psikologis, bahkan yang berkaitan dengan mahar, terjadinya perkosaan dalam perkawinan,

Terjadinya kerusakan alat kelamin, dan pemerasan secara seksual.

kekerasan terhadap fisik, seksual dan psikologis yang sering menimpa di kalangan perempuan diantaranya perkosaan, pelecehan seksual di intansi dan lembaga pendidikan, Human Trafiking dan pelacuran secara paksa dan lain sebagainya.

Adapun jenis tindakan kekerasan terhadap perempuan menurut Sri Nurdjunaida dalam jurnalnya yang berjudul "pengertian kekerasan terhadap perempuan Jurnal sekilas kekerasan pada perempuan” terjadi dalam beberapa bentuk tindakan kekerasan, yaitu:

Yang pertama, Tindak kekerasan secara fisik maksudnya yaitu suatu perlakuan yang memeiliki tujuan melukai, menganiaya baik dengan menggunakan alat atau tidak. Bentuknya bisa berupa tamparan, pemukulan, penjambakan, mendorong secara kasar atau dengan benda tajam yang dapat melukai korban dan bahkan bisa menyebabkan hilangnya nyawa.

Yang kedua, yaitu Tindakan kekerasan secara psikologis atau 
KHAZANAH MULTIDISIPLIN

VOL 2 NO 12021

https://journal.uinsgd.ac.id/index.php/kl

kejiwaan maksudnya yaitu tindakan yang memiliki tujuan untuk menekan kejiwaan seseorang dengan cara merendahkan harkat martabat seorang perempuan, baik secara lisan ataupun secara perbuatan yang dapat merugikan orang lain. Yang dapat menimbulkan efek trauma, takut, tidak percaya diri, dan tekanan berat pada psikis seseorang.

Yang ketiga, yaitu Tindak kekerasan secara seksual maksudnya kekerasan yang merendahkan martabat perempuan yang bermotif seksual, misalnya pelecehan seksual, perkosaan, dan pencabulan. Tindakan tersebut dikategorikan pada dua bentuk kekerasan yaitu kekerasan fisik dan psikologis.

Yang keempat adalah penelantaran secara ekonomi yang mana bentuk ini termasuk kekerasan terhadap ekonomi, misalnya tidak diberi nafkah secara rutin atau nafkah yang tidak mencukupi, larangan untuk bekerja secara layak dan memberikan pembatasan secara berlebihan dalam segi ekonomi.

\section{Politik hukum kekerasan sexsual dalam RKUHP}

Upaya pemerintah dalam memerangi tindak pidana kekerasan seksual yang terjadi di masyarakat di implementasikan dalam Rancangan Undang-undang mengenai penghapusan kekerasan seksual. Upaya ini merupakan bentuk perwujudan dari tanggungjawab Negara yang diharapkan mampu melindungi dan memperbaiki kondisi psikologis korban, baik korban kekerasan dalam bentuk pisik maupun psikologis yang belum terdapat dalam peraturan undang-undang, terlebih terhadap perempuan dan anak yang selama ini rentan menjadi korban kekerasan seksual yang seharusnya mendapatkan perlindungan dari Negara.

Rancangan Undang-undang ini meliputi pencegahan kekerasan seksual dan penanganan untuk korban yang terkena kekerasan seksual. Selain itu, RUU ini juga mencakup ruang lingkup penindakan pelaku melalui pemidanaan dan rehabilitasi pelaku untuk mencegah keberulangan.

Ruang lingkup pencegahan meliputi penjabaran ketentuan yang 
mewajibkan Lembaga Negara, Korporasi dan lembaga masyarakat menyusun dan menyelenggarakan kebijakan, program, dan anggaran untuk mencegah terjadinya kekerasan seksual. Lembaga Negara, Korporasi dan lembaga masyarakat juga wajib

melakukan pencegahan dengan cara mengubah atau menghapus segala bentuk praktek tradisi dan kebijakan diskriminatif yang menjadikan tubuh dan seksualitas sebagai sasaran. Pengintegrasian materi Hak Asasi Manusia, kepekaan Gender, materi ajar seksualitas dan kesehatan reproduksi di setiap jenjang pendidikan dan bagi masyarakat; dan pembangunan komunitas masyarakat anti kekerasan seksual; adalah beberapa langkah penerjemahan kewajiban pencegahan kekerasan seksual. Hal lainnya antara lain penetapan kriteria bukan pelaku kekerasan seksual dalam setiap perekrutan calon pejabat atau calon pekerja, pembangunan sarana dan prasarana yang berkontribusi pada pencegahan kekerasan seksual dan penetapan regulasi perlindungan perempuan dalam layanan publik oleh Lembaga Negara, Korporasi dan lembaga masyarakat.

Dalam ruang lingkup penanganan bagi korban, RUU ini merumuskan ketentuan pemulihan bagi korban berdasarkan konsep Pemulihan Dalam Makna Luas. Dalam RUU ini, unsur pemulihan meliputi korban, keluarga, pendamping dan komunitas, serta Negara sebagai pemangku kewajiban. RUU ini juga merumuskan kewajiban Pemerintah dan Pemerintah Daerah dalam penyediaan layanan komprehensif dan berkesinambungan melalui sistem pusat pelayanan terpadu bagi korban.

Rumusan Pemulihan bagi korban dalam RUU ini adalah kebutuhan khusus korban kekerasan seksual yang tidak dapat dituangkan secara spesifik dalam Kitab Undang- Undang Hukum Acara Pidana (KUHAP). Sehingga demi terwujudnya Pemulihan Dalam Makna Luas bagi korban kekerasan seksual, maka kehadiran RUU ini sebagai lex specialist UU khusus dari KUHP mutlak diperlukan.

Seiring terjadinya berbagai kendala yang dihadapi oleh perempuan korban kekerasan seksual dalam menjalani proses peradilan pidana, RUU 
ini merumuskan hukum acara khusus untuk mengeliminasi berbagai hambatan tersebut dan menguatkan proses peradilan yang menghindarkan reviktimisasi dan kriminalisasi korban. Termasuk di dalamnya penentuan kriteria Penyidik, Jaksa Penuntut Umum dan Hakim yang menangani perkara harus memiliki kemampuan khusus penanganan perkara kekerasan seksual. Rumusan bab hukum acara ini adalah penerjemahan dari konsep Sistem Peradilan Pidana Terpadu Penanganan Kasus Kekerasan Terhadap Perempuan (SPPT- PKKTP). Sehingga dengan demikian, rumusan ini juga menunjukkan urgensi RUU ini sebagai lex specialist, terutama karena kekerasan seksual adalah tindak pidana yang menyasar tubuh dan seksualitas korban sehingga penanganannya tidak bisa disamakan dengan tindak pidana umum.

Maka mengingat berbagai kekhususannya, kehadiran RUU Penghapusan Kekerasan Seksual sangatlah dibutuhkan.

Adapun Perbedaan antara RUU penghapusan kekerasan seksual dengan KUHP yaitu sebagai berikut : Dalam aspek jenis kekerasan seksual RUU penghapusn kekerasan seksual menguraikan definisi 9 jenis kekerasan sedangkan dama KUHP jenis kekerasan seksual terbatas pada perkosaan dan pencabulan, aspek unsur atau definisi kekerasan seksual sesuai bentuk-bentuknya dalam RUU penghapusan kekerasan seksual menguraikan unsur 9 tindak pidana kekerasan seksual sedangkan KUHP terbatas pada unsur perkosaan dan pencabulan, pengaturan tentang perkosaan masih belum menjamin perlindungan hak korban, aspek pemidanaan terhadap korporasi dalam RUU Penghapusan kekerasan sesksual itu diatur secara eksplisit misalnya ketika suatu korporasi melakukan tindak pidana kekerasan seksual maka dalam hal proses penyidikan, penuntutan dan pemidanaannya pun dilakukan langsung terhadap korporasi tersebut atau terhadap pengurusnya, sedangkan dalam KUHP tidak ada pengaturannya. Aspek pemidanaan tindak pidana kekerasan seksual dalam RUU Penghapusan kekerasan seksual pada rumusannya mengandung ancaman 2 pidana pokok dan 9 pidana 
tambahan yang dijatuhkan atas 9 tindak pidana kekerasan seksual berdasarkan pemberatan atas tindak pidana sedangkan KUHP terbatas pada pemidanaan perkosaan dan pencabulan. Aspek pidana pokok berupa rehabilitasi khusus kepada pelaku dalam RUU penghapusan kekerasan seksual rehabilitasi khusus yang memiliki tujuan merubah cara berfikir, sudut pandang pelaku, dan perilakunya, serta memberikan efek jera agar tidak mengulangi kejahatan yang sama. Rehabilitasi khusus dijatuhkan terhadap terpidana anak yang berusia 14 tahun atau terpidana pada perkara pelecehan seksual sedangkan dalam KUHP tidak diatur, aspek pidana tambahan berupa penggantian biaya yang dituntut oleh korban atau keluarganya dengan menempuh jalan litigasi, ditetapkan sebagai hukuman tambahan kepada terpidana, sedangkan di KUHP tidak diatur.

Aspek hukuman tambahan yang dijatuhkan kepada terpidana berupa pengambilan keuntungan yang diperoleh dari tindakan yang dilakukannya dalam RUU penghapusan kekerasan seksual diatur sebagai ancaman pidana tambahan atas tindak pidana pemaksaan pelacuran, sedangkan dalam KUHP tidak diatur. RUU penghapusan kekerasan seksual, penyelenggaraan pidana tambahan kerja sosial mempertimbangkan tindak pidana kekerasan seksual yang dilakukan pelaku, kondisi psikologis pelaku dan identifikasi tingkat resiko yang membahayakan sedangkan dalam KUHP tidak diatur, aspek pidana tambahan berupa pembinaan khusus dalam RUU penghapusan kekerasan seksual pidana tambahan pembinaan khusus meliputi hal-hal yang berkaitan dengan perawatan dibawah psikolog dan atau psikiater, peningkatan kesadaran hukum, pendidikan intelektual, pengubahan sikap dan perilaku, perawatan kesehatan jasmani dan rohani dan reintegrasi perilaku tanpa kekerasan seksual sedangkan dalam KUHP tidak diatur, aspek pidana tambahan berupa pencabutan hak asuh dalam RUU penghapusan kekerasan seksual sebagai pidana tambahan kepada pelaku yang merupakan orang tua atau kerabat korban sedangkan dalam KUHP tidak diatur, aspek pidana tambahan berupa pencabutan hak politik dalam RUU penghapusan kekerasan seksual sebagai pidana 
tambahan pelaku kekerasan seksual yang merupakan pejabat public sedangkan dalam KUHP tidak diatur, aspek pidana tambahan berupa pencabutan hak menjalankan pekerjaan tertentu dalam RUU penghapusan kekerasan seksual sebagai pidana tambahan terhadap pelaku kekerasan seksual yang merupakan majikan yang memberikan pekerjaan atau seseorang yang terlibat dan bertanggung jawab dalam pengelolaan lembaga pendidikan, keagamaan, sosial, atau tempat lain yang seharusnya aman dan melindungi anak dan perempuan dalam KUHP tidak diatur, aspek pidana tambahan berupa pencabutan jabatan atau profesi dalam RUU penghapusan kekerasan seksual sebagai pidana tambahan terhadap pelaku kekerasan seksual yang merupakan penegak hukum atau pejabat KUHP tidak mengatur, aspek pidana tambahan berupa pengumuman putusan hakim dalam RUU penghapusan kekerasan seksual sebagai pemberatan antara lain jika pelaku kekerasan tersebut melakukan kekerasan seksual dalam kondisi darurat misalnya kondisi darurat bencana alam, darurat perang, dan konflik sosial atau darurat lainnya sedangkap dalam KUHP tidak mengaturnya.

\section{SIMPULAN}

Salah satu peran politik hukum dalam membuat suatu kebijakan yaitu mengakomodir setiap hukum yang diciptakan. Bahwa politik hukum memiliki peran penting dalam suatu kebijakan karena dibuat untuk menjadi acuan dan landasan dalam perumusan menentukan nilai dan menetapkan hukum Negara. Adanya RUU Penghapusan Kekerasan Seksual ini merupakan produk hukum yang mana memberikan kebijakan kepada Negara agar lebih diperhatikan korban dari perilaku kekerasan tersebut, sebelum adanya aturan ini sering kali hanya pelaku saja yang ditindak namun korban dari kekerasan seksual ini diabaikan, padahal yang seharusnya ditangani itu pelaku dan korban, karena korban lebih rentan dan dapat menimbulkan trauma bagi si korban atas kejadian tersebut, pada dewasa ini perlu adanya kebijakan dalam hal tersebut. Untuk mewujudkan 
KHAZANAH MULTIDISIPLIN

VOL 2 NO 12021

https://journal.uinsgd.ac.id/index.php/kl

sistem hukum yang diperlukan dalam mencapai tujuan masyarakat, maka aturan politik hukum pidana ini merupakan aturan yang diharapkan mampu menjadi solusi yang tepat dan menjadi alternatif hukum di Indonesia demi mewujudkan sistem hukum yang baik.

\section{DAFTAR PUSTAKA}

Nawawi Arif, B. (2005). Bunga Rampai Kebijakan Hukum Pidana. Bandung. Citra Aditya Bakti.

Nazmi Yunas, D. (1992). Konsepsi Negara Hukum. Padang. Angkasa Raya.

Hasbi, E . ( 2016). Kriminologi. Bandung. Tim Redaksi Pustaka Setia.

Mahfud, MD. ( 2009). Politik Hukum Di Indonesia. Jakarta. Pt Rajagrafindo Persada.

Ridwan, HR. (2006). Hukum Administrasi Negara. Jakarta. Pt Raja Grafindo Persada.

Sokanto. S. (2015). Penelitian Hukum Normative Suatu Tinjauan Singkat. Depok. Rajawali.

Nurdjunaida, S. (2013). Pengertian Kekerasan Terhadap Perempuan. Jurnal Sekilas Kekerasan Pada Perempuan, 9, 21-23 .

Harnoko, R. (2010). Dibalik Tindak Kekerasan Terhadap Perempuan. Muwwazan. Malang.

Yulia, R. (2012). Politik Hukum Pidana Dalam Perlindungan Terhadap Korban Kejahatan Di Indonesia. Banten.Universitas Sultan Ageng Tirtayasa. 